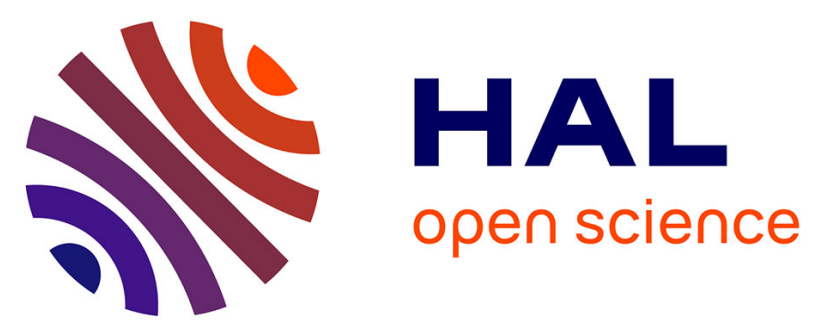

\title{
A Simple Model for Hardness and Residual Stress Profiles Prediction for Low-Alloy Nitrided Steel, Based on Nitriding-Induced Tempering Effects
}

\author{
Simon Thibault, Christine Sidoroff, Sébastien Jégou, Laurent Barrallier, \\ Grégory Michel
}

\section{To cite this version:}

Simon Thibault, Christine Sidoroff, Sébastien Jégou, Laurent Barrallier, Grégory Michel. A Simple Model for Hardness and Residual Stress Profiles Prediction for Low-Alloy Nitrided Steel, Based on Nitriding-Induced Tempering Effects. HTM J. Heat Treatm. Mat., 2018, 73 (5), pp.235-245. hal01905706

\section{HAL Id: hal-01905706 \\ https://hal.science/hal-01905706}

Submitted on 26 Oct 2018

HAL is a multi-disciplinary open access archive for the deposit and dissemination of scientific research documents, whether they are published or not. The documents may come from teaching and research institutions in France or abroad, or from public or private research centers.
L'archive ouverte pluridisciplinaire HAL, est destinée au dépôt et à la diffusion de documents scientifiques de niveau recherche, publiés ou non, émanant des établissements d'enseignement et de recherche français ou étrangers, des laboratoires publics ou privés. 


\title{
A simple model for hardness and residual stress profiles prediction for low-alloy nitrided steel, based on nitriding-induced tempering effects
}

\author{
Simon THIBAULT ${ }^{1,3}$, Christine SIDOROFF ${ }^{2,3}$, Sébastien JEGOU ${ }^{4}$, Laurent BARRALLIER ${ }^{4}$, \\ Grégory MICHEL ${ }^{3}$ \\ ${ }^{1}$ Safran Tech, Magny les Hameaux - France, simon.thibault@safrangroup.com \\ ${ }_{2} N T N$-SNR, Annecy - France, christine.sidoroff@ntn-snr.com \\ ${ }^{3}$ IRT-M2P, Metz-France, gregory.michel@irt-m2p.fr \\ ${ }^{4}$ MSMP Laboratory, Arts et Métiers ParisTech, Aix-en-Provence-France, sebastien.jegou@ensam.eu
}

\begin{abstract}
Nitriding of low-alloy steels is widely used for gears and bearings in aerospace industry. Some highly stressed surfaces require high nitrided depth, which involves long time/high temperature nitriding treatment. This study focused on identifying process parameter effects on hardness and residual stress profiles in a large range of nitriding time and temperature. We demonstrate that core and case can be considered as two materials, softening of which can be predicted by two tempering laws. In addition, a basic relationship was derived from the nitriding depth and a pseudo-diffusion coefficient, allowing prediction of the hardness profile. Residual stress results show that the diffusion controlled effect can also be used to predict residual stress profile affected depth. Likewise, the tempering controlled effect can be used to predict surface and maximum values of the residual stress profile.
\end{abstract}

Keywords

Nitriding, modelling, hardening, tempering, residual stress

\section{Introduction}

The aerospace industry is continuously looking for weight reduction. Thus, reducing design margins between applied stress and materials strength becomes necessary. In the case of gears and bearings, this can be achieved by mastering surface engineering, especially through thermochemical heat treatments. Recent developments of mechanical design methods at a mesoscopic scale, allow to check if the local mechanical properties are able to undergo a given applied stress field ([Walvekar, 2017], [Savaria, 2015], [Weil, 2018], [Ghribi, 2016], [HassaniGangaraj, 2014]). These methods, generally based on the concept of local mechanical limit [Spies, 1993], use hardness profile as strength indicator and residual stress profile as a part of the global stress field. On this basis, a process modelling able to provide both profiles for given process parameters, can be of interest. It can be used to specify process parameters for a given part, or to identify the influence of desired or undesired process parameter changes on mechanical performance.

In the specific case of low-alloy steel nitriding, such models are reported in literature. They are based on combined diffusion and precipitation complex calculations ([Jung, 2015], [Barrallier, 1992], [Jegou, 2016]). Micro-macro mechanical models are then employed to compute residual stress resulting from local differential density of the metallurgical phases formed during nitriding. Nitrogen profile calculations are also used for hardness prediction. Empirical formulations can be found between hardness and nitrogen concentration [Hiraoka, 2016]. They are not suitable for long time or high temperature nitriding required by some highly stressed parts. In fact, they do not take into account decrease of core and case hardness and the important profile shape change induced 
by such treatments. More recently, a similar model was proposed to take into account the temperature effect on type and morphology of nitrides, which affect differently local hardness [Weil, 2018]. Finally, we can mention a method linking residual stress profiles to hardness profile [Leskovsek, 2008]. It obviously requires experiments to get the hardness profiles.

The aim of the present work is to propose a tool for engineer for an easy estimation of hardness and residual stress profiles from process parameters, without complex thermodynamics and mechanical calculation steps.

\section{Experimental procedure}

Coupons of $45 \mathrm{~mm}$ in diameter and $12 \mathrm{~mm}$ height were cut from a $80 \mathrm{~mm}$ diameter bar of normalized and annealed E33CrMoV12-9 steel grade. Then, the samples were quenched (austenitized at $920{ }^{\circ} \mathrm{C}$, quenched in oil at $50{ }^{\circ} \mathrm{C}$ ) and air tempered $\left(2\right.$ hours at $615^{\circ} \mathrm{C}$ ) to achieve an ultimate tensile stress of around $1300 \mathrm{MPa}$ and $410 \mathrm{HV} 10$ hardness. Surfaces were then ground for a surface finish of $0,4 \mu \mathrm{m}$ arithmetic roughness.

Nitriding treatments were performed in an ALD industrial nitriding furnace with a large range of nitriding times and temperatures (from 4 to 200 hours and from 480 to $590{ }^{\circ} \mathrm{C}$ ). The atmosphere control during nitriding was ensured by a $\mathrm{H}_{2} \mathrm{SMART}^{\mathrm{TM}}$ system (UPC). Regulation of the nitriding potential $\mathrm{K}_{\mathrm{N}}$ was made by adjusting ammoniac $\left(\mathrm{NH}_{3}\right)$ and dissociated ammoniac $\left(\mathrm{N}_{2}+\mathrm{H}_{2}\right)$ flow rates. All nitriding experiments were done with a $\mathrm{K}_{\mathrm{N}}$ leading to a continuous compound layer formation in the temperature range explored (i.e. $\mathrm{K}_{\mathrm{N}}>0.5 \mathrm{~atm}^{-0,5}$ ). Thus, the chemical boundary condition for the diffusion layer is controlled by the maximal nitrogen content one can introduce in the steel (sum of nitrogen content in solid solution, alloying element nitrides and excess nitrogen [Somers, 1989]) which only depends on steel composition and temperature.

3 Microstructure in cross section was observed by optical microscopy after Nital and Murakami etching. Cross section hardness profiles were obtained with a Qness Q60+ micro hardness testing machine using Vickers indentor and a $0.5 \mathrm{kgf}$ force. For each sample, three hardness profiles were measured. A mean hardness profile was then calculated. Residual stress profile assessment was carried out by X-ray diffraction with a Elphyse SetX device using $\mathrm{Cr}-\mathrm{K} \alpha$ radiation on the $\{211\}$ diffracting plane of $\alpha$-Fe. The $\sin ^{2} \psi$ method was used to determine the mean residual stresses in $\alpha-\mathrm{Fe}\left(S_{1}^{\{211\}}=-1.25 .10^{-6} \mathrm{MPa}^{-1}, \frac{1}{2} S_{2}^{\{211\}}=5.85 .10^{-6} \mathrm{MPa}^{-1}\right)$ along the nitriding depth. Electro-chemical surface layer removal was performed for indepth profiling. Nitrogen and carbon content profiles were obtained thanks to Wavelength Dispersion Spectroscopy (WDS) using Cameca SX100 electron probe micro analyser. As for hardness profiles, three measurements were performed and a mean curve was calculated. Results

Typical results are given in Figure 2 and Figure 3 for a nitriding treatment of 120 hours at $550^{\circ} \mathrm{C}$. Optical microscopy observations for both etching are presented in Figure 1. The Nital etching reveals a fine tempered martensitic structure and a homogeneous compound layer $\left(\varepsilon+\gamma^{\prime}\right)$. The Murakami etching reveals intergranular cementite precipitation, also called "seagulls". This is due to carbon migration which results from substitution of originals carbides to globular nitrides. 


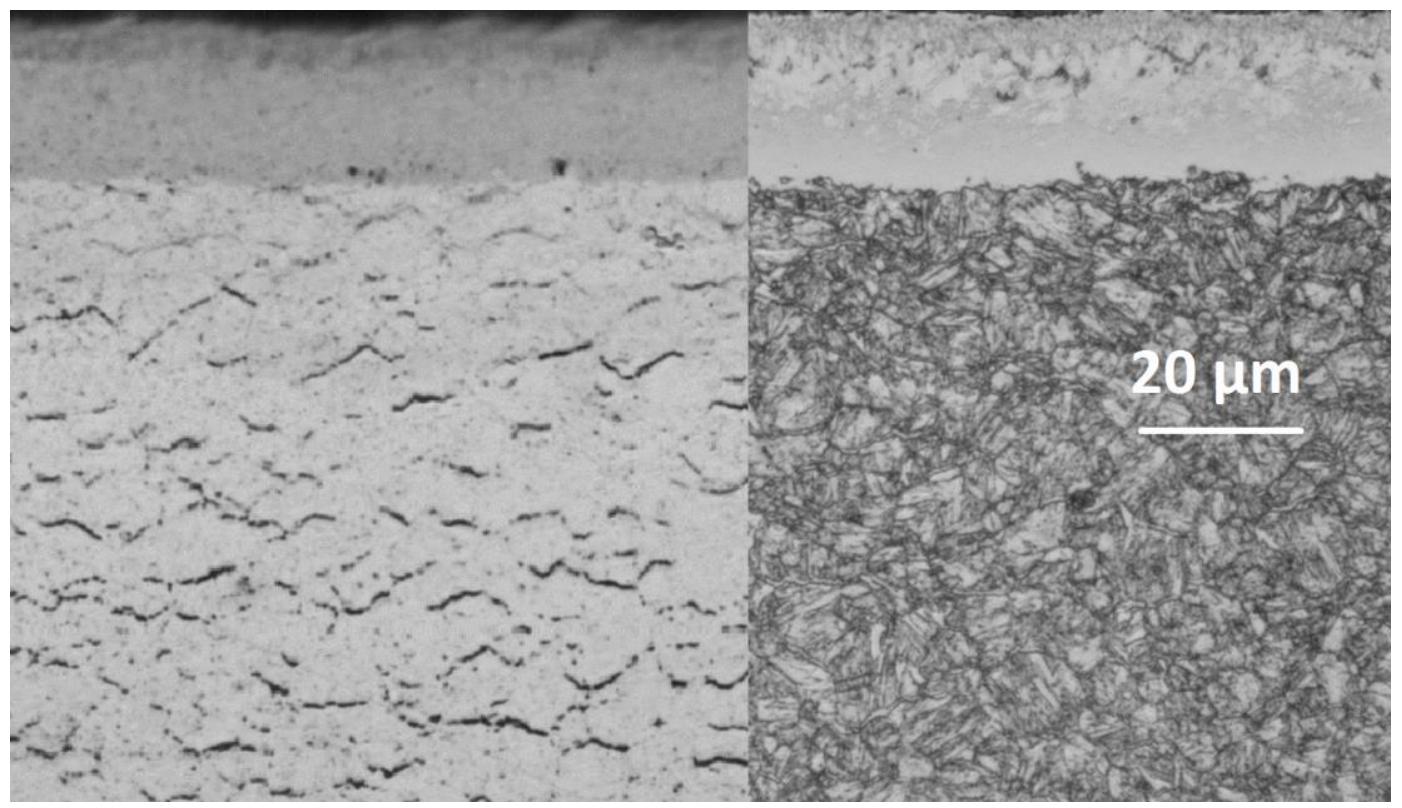

Figure 1: Typical microstructure of nitrided E33CrMoV12-9 after Murakami (left) and Nital (right) etching.

WDS measurements shows that nitrogen is present in the first $0,8 \mathrm{~mm}$. The sharp gradient from 0,6 to $0,8 \mathrm{~mm}$ is due to the precipitation front of $\mathrm{MN}$, where $\mathrm{M}$ can be $\mathrm{Cr}$, Mo or $\mathrm{V}$ (mainly $\mathrm{Cr}$ ) [Ginter, 2006]. The carbon content baseline modification (\%wt $\mathrm{C}=0.32$ initially) can be linked with two phenomena: decarburizing during the first steps of nitriding, and substitution of carbides by nitrides [Jegou, 2018]. For this nitriding treatment, surface hardness is $740 \mathrm{HV}$. Core hardness suffered a slight softening to reach $370 \mathrm{HV}$. The residual stress profile shows the typical form reported in literature, with an affected depth higher than the hardness one, and a maximum compressive stress of $-400 \mathrm{MPa}$ in the diffusion layer.

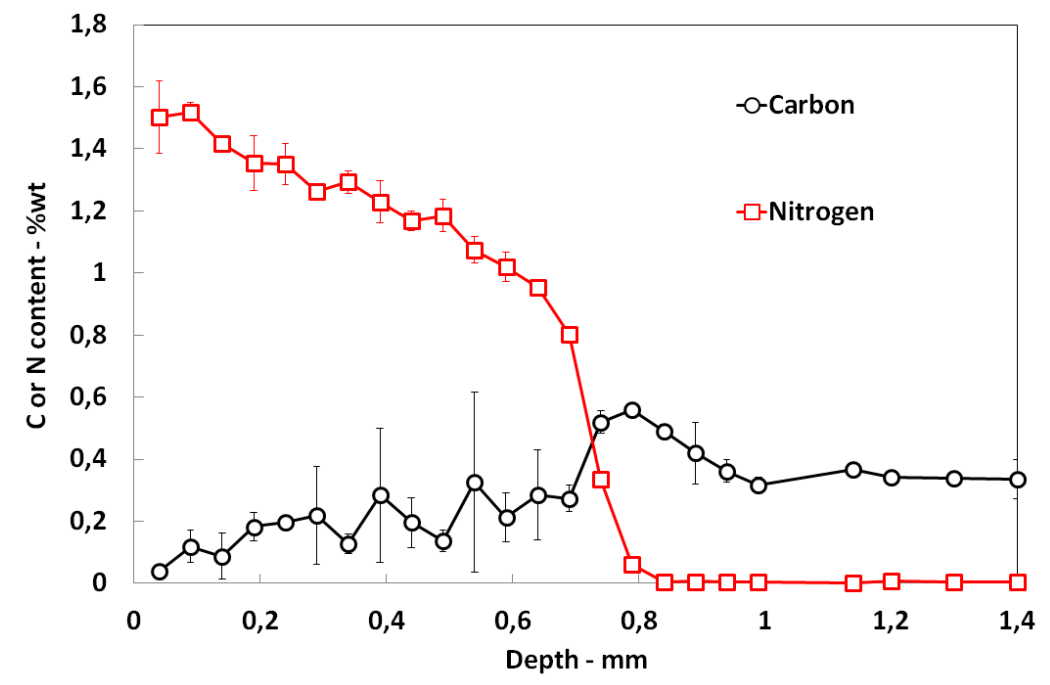

Figure 2: WDS nitrogen and carbon content profile for the 120 hours $-550{ }^{\circ} \mathrm{C}$ nitriding experiment 

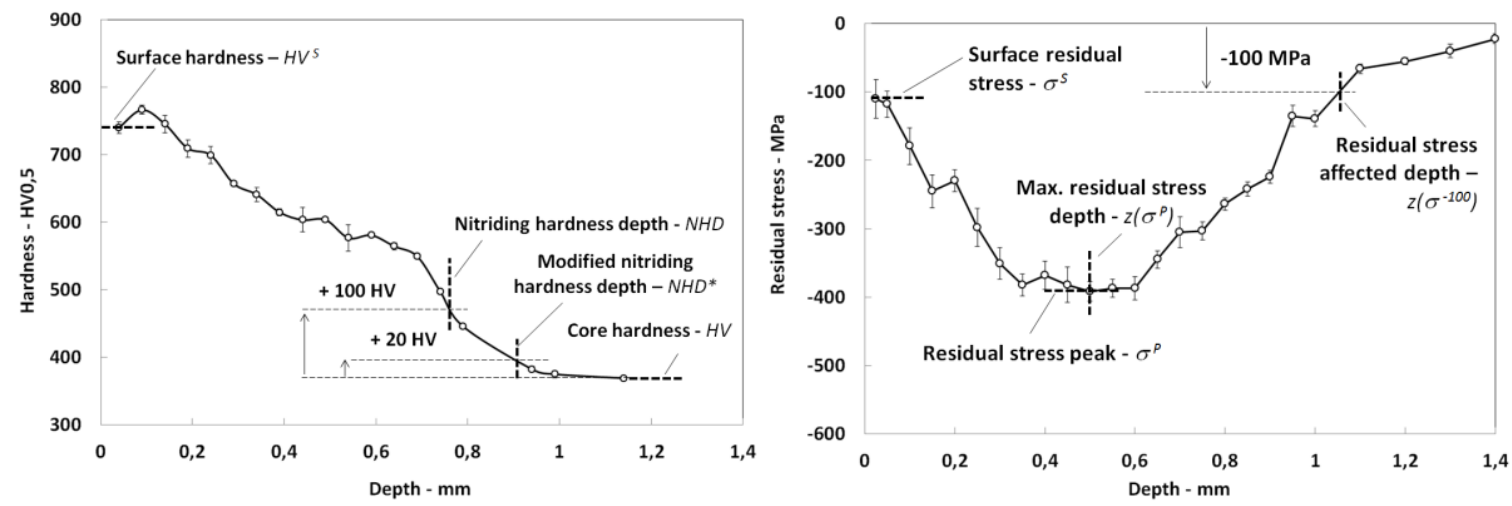

Figure 3: Hardness (left) and residual stress (right) profiles for the 120 hours $-550{ }^{\circ} \mathrm{C}$ nitriding experiment and relevant indicators

Values of interest, displayed on Figure 3, were collected for all nitriding experiments. These indicators will be designated in the following sections as detailed in Table 1.

\begin{tabular}{|c|c|c|c|c|c|c|c|}
\hline $\begin{array}{l}\text { Hardness } \\
\text { indicator }\end{array}$ & Definition & $\pi \mathrm{T}^{\circ}$ & $\pi t$ & $\begin{array}{l}\text { Residual } \\
\text { stress } \\
\text { indicator }\end{array}$ & Definition & $\pi T$ & $\pi t$ \\
\hline $\mathrm{HV}$ & Core hardness & $=(\searrow)$ & $=(\searrow)$ & $\sigma^{\mathrm{P}}$ & $\begin{array}{l}\text { Residual stress } \\
\text { peak(extremum) }\end{array}$ & $\searrow$ & $\searrow$ \\
\hline $\mathrm{HV}^{\mathrm{S}}$ & Surface hardness $^{1}$ & ע & $\searrow$ & $\sigma^{\mathrm{S}}$ & Surface residual stress & ע & $\searrow$ \\
\hline NHD* & $\begin{array}{l}\text { Modified nitriding hardness depth } \\
\text { (HV Core }+20)\end{array}$ & オ & スス & $\mathrm{z}\left(\sigma^{\mathrm{P}}\right)$ & $\begin{array}{l}\text { Maximum residual } \\
\text { stress depth }\end{array}$ & ス & スス \\
\hline NHD & $\begin{array}{l}\text { Nitriding hardness depth } \\
\text { (HV Core }+100)\end{array}$ & オ & スス & $\mathrm{z}\left(\sigma^{-100}\right)$ & $\begin{array}{c}\text { Residual stress } \\
\text { affected depth } \\
\text { (Depth at which } \\
\text { residual stresses } \\
\text { decrease back to-100 } \\
\mathrm{MPa} \text { ) }\end{array}$ & ス & スス \\
\hline
\end{tabular}

${ }^{1}$ Note that "surface hardness" does not strictly result from a surface measurement but refers to the first cross-section reading of microhardness

Table 1: Indicator definition and their evolution for an increase in nitriding time or temperature. ( $\nearrow$ means moderate increase $-\searrow$ means moderate decrease $-\searrow \searrow$ or $\lambda \nearrow$ mean important decrease or increase $-=$ means no change - parenthesis indicate change occurring for particularly high nitriding duration or time)

Since they follow the classical and widely reported trends ([Spies, 2014][ASM, 1991][Ginter, 2006]), the effect of nitriding time and temperature on hardness, residual stress and case depth are given in a simple way in Table 1 but not detailed. Increasing temperature or time resulted in an increase of case depth and in a decrease of case hardness and compressive residual stress. Long time and high temperature treatments can result in a decrease of core hardness [Hoja, 2015].

As Ginter [Ginter, 2006] did in previous works, local hardness was plotted as a function of nitrogen content for various nitriding experiments, leading to different hardening laws. Two representations are proposed in Figure 4. The first one shows hardening laws at the surface for different nitriding durations at $550{ }^{\circ} \mathrm{C}$. The second one shows hardening laws for 120 hours nitriding at different temperatures. One can see that neither temperature nor duration of nitriding treatment is sufficient to describe a hardening law, which seems to obey to a combined time-temperature effect. 

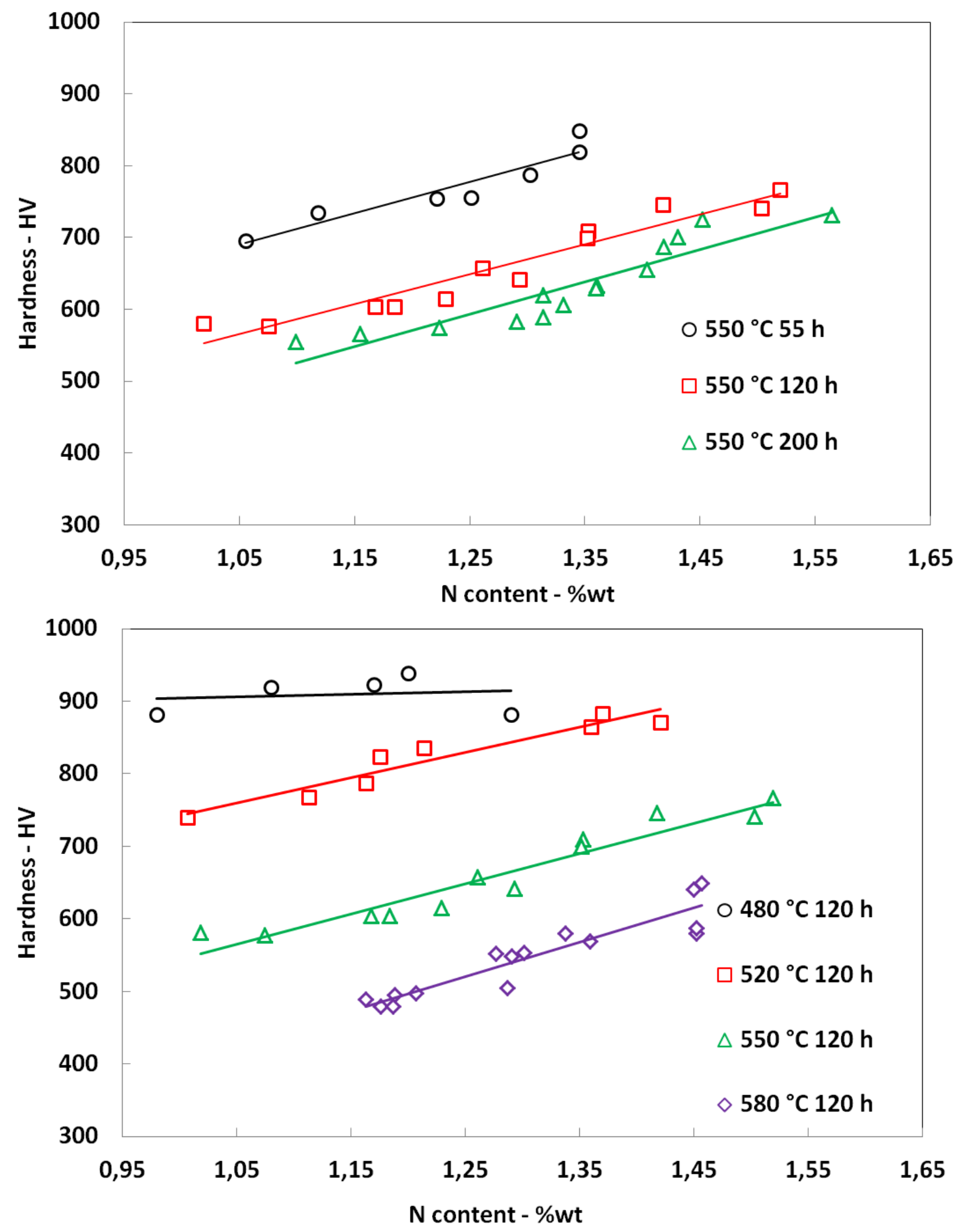

Figure 4: Surface hardening laws for nitriding performed at same temperature but different time (left) and for nitriding performed at different temperature but for a given time (right)

4 Model formulation

To depict the combined time/temperature effect mentioned above, and as did Hoja [Hoja, 2015] for core hardness, we propose to link case and core hardness but also residual stress to the well- 
known Hollomon-Jaffe [Hollomon, 1945] tempering parameter, which allows time/temperature equivalences. Since this parameter was initially used for tempering treatment, we will call it $H P_{N I T}$ to explicit that, in our case, it represents the intensity of nitriding-induced tempering. As in the original formulation, $H P_{N I T}$ is calculated thanks to Eq. [1].

$$
H P_{N I T}=\frac{(T+273.15)\left(C+\log _{10}(t)\right)}{1000}
$$

Where $T$ is the nitriding temperature in Celsius degrees, $t$ is the nitriding time in hours, and $C$ is a material parameter, generally set to 20 for martensitic steels.

As for martensitic steel tempering, the higher the $H P$, the lower the hardness. Final surface hardness and residual stresses after nitriding can be considered as the consequence of tempering of freshly nitrogen saturated steel. We assume that, once surface composition is stabilized (few hours [Fallot, 2015][Jegou, 2018]), nitriding acts as a simple tempering treatment on the diffusion layer, leading to phase transformations in terms of size and volume of nitrides and grain boundaries carbides (cementite) [Locquet, 1997],[Barrallier, 2014].

Four points of interest are needed to draw the calculated hardness profile. The first ones are the surface and core hardness values, respectively named $H V^{S}$ and $H V$. Figure 5 represents experimental values of $H V^{S}$ and $H V$ versus $H P_{N I T}$. A good correlation can be found between surface hardness decrease and $H P_{N I T}$, whatever the nitriding temperatures and times considered. For core hardness, a transition is observed when $H P_{N I T}$ reaches the critical $H P$ value corresponding to the initial tempering treatment. We call this parameter, the Hollomon-Jaffe reference parameter for core steel, $H P_{0}$ (in our case, $H P_{0}=18$ ). If $H P_{N I T}$ exceeds $H P_{0}$, core softening occurs.

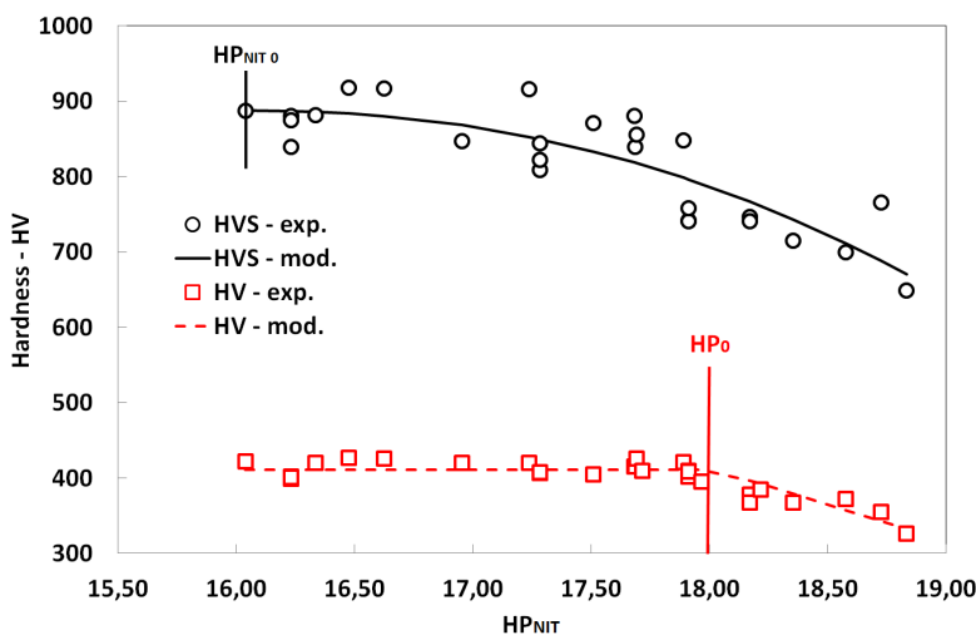

Figure 5: Surface hardness $H V^{S}$ and core hardness $H V$ as a function of $H P_{N I T}$ parameter

Thus, the following functions (equations [2,3]) can be used to predict $H V^{S}$ and $H V$ as a function of $H P_{N I T}$ :

$$
\begin{gathered}
H V=H V_{0}-\beta<H P_{N I T}-H P_{0}>\quad[2] \\
H V^{S}=H V_{0}^{S}-\beta^{S}\left(H P_{N I T}-H P_{N I T ~ 0}\right)^{n}
\end{gathered}
$$


Where $H V_{0}$ is the core hardness before nitriding. $H V^{S_{0}}$ is the reference surface hardness corresponding to the surface hardness reached for the lowest value of $H P_{N I T}$ nitriding experiment, called $H P_{\text {NIT } 0} . \beta, \beta^{S}$ and $n$ are dimensionless model parameters. $<>$ are the Mac Cauley brackets.

Nitriding hardness depth $N H D$, in $\mathrm{mm}$, can be related to nitriding time $\mathrm{t}$ and temperature $T$ through a simplified diffusion calculation described in Eq. [4].

$$
N H D=1000 \sqrt{D_{0} e^{\frac{E_{D}}{8.314(T+273.15)}} \cdot 3600 . t}
$$

Where $D_{0}$ is a pseudo-diffusion coefficient in $\mu \mathrm{m}^{2} \mathrm{~s}^{1}{ }^{1}$ and $E_{D}$ is the activation energy in $\mathrm{J} . \mathrm{mol}^{-1}$. Comparison between experimental data and calculation of $N H D$ is given in Figure 6.

To complete the hardness profile, a modified $N H D$, called $N H D^{*}$ was defined (see Figure 3 ). Figure 7 shows that this indicator can be directly linked to NHD with a linear relation defined in Eq. [5].

$$
N H D^{*}=\alpha \cdot N H D \quad[5]
$$

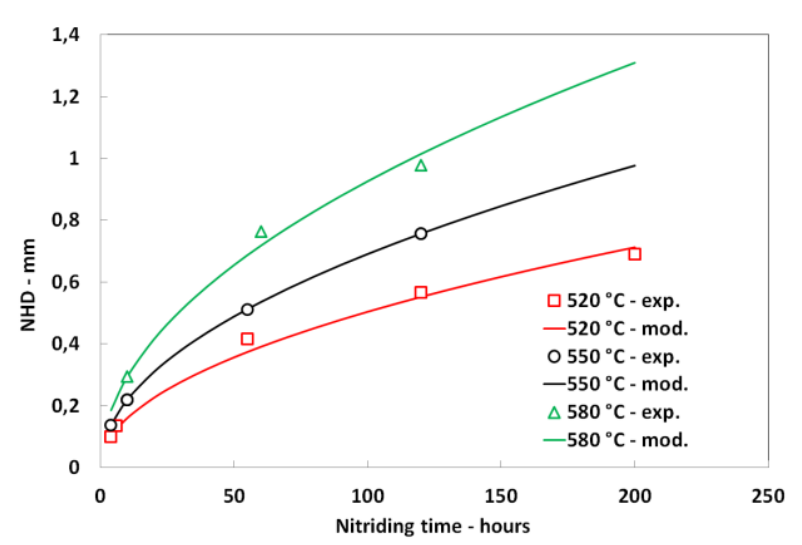

Figure 6 : Nitriding hardness depth $N H D$ as a function of nitriding time $t$ for three nitriding temperature $T$

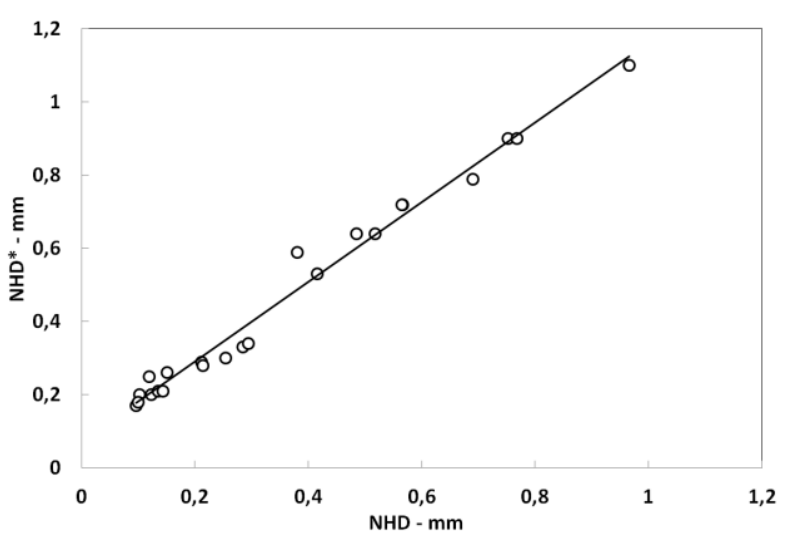

Figure 7: Modified nitriding hardness depth $N H D^{*}$ as a function of $N H D$

$H P_{N I T}$ was also successfully used to describe the evolution of residual stress values at the surface $\left(\sigma^{S}\right)$ and at the peak $\left(\sigma^{P}\right)$ as a function of nitriding parameters (see Figure 8). Both values can be calculated with the type of function previously used for hardness (Eq. [6, 7]).

$$
\begin{array}{ll}
\sigma^{S}=-\sigma_{0}^{S}+\lambda^{S}\left(H P_{N I T}-H P_{N I T ~ 0}\right)^{m} & {[6]} \\
\sigma^{P}=-\sigma_{0}^{S}+\lambda^{P}\left(H P_{N I T}-H P_{\text {NIT } 0}\right)^{m} & \text { [7] }
\end{array}
$$

Where $\sigma_{0}$ is the reference surface residual stress corresponding to the surface residual stress reached for the lowest value of $H P_{N I T}$ nitriding experiments called $H P_{N I T} 0 . \lambda^{S}, \lambda^{P}$ and $m$ are dimensionless model parameters.

Finally, maximum residual stress depth $\left(z\left(\sigma^{P}\right)\right)$ and residual stress affected depth $\left(z\left(\sigma^{100}\right)\right)$ are derived from $N H D$ calculated values with linear relations given in Eq. [8,9] (see Figure 8 and Figure 9). 


$$
\begin{aligned}
\mathrm{z}\left(\sigma^{P}\right) & =\chi \cdot N H D \\
\mathrm{z}\left(\sigma^{-100}\right) & =\rho \cdot \mathrm{z}\left(\sigma^{P}\right)
\end{aligned}
$$

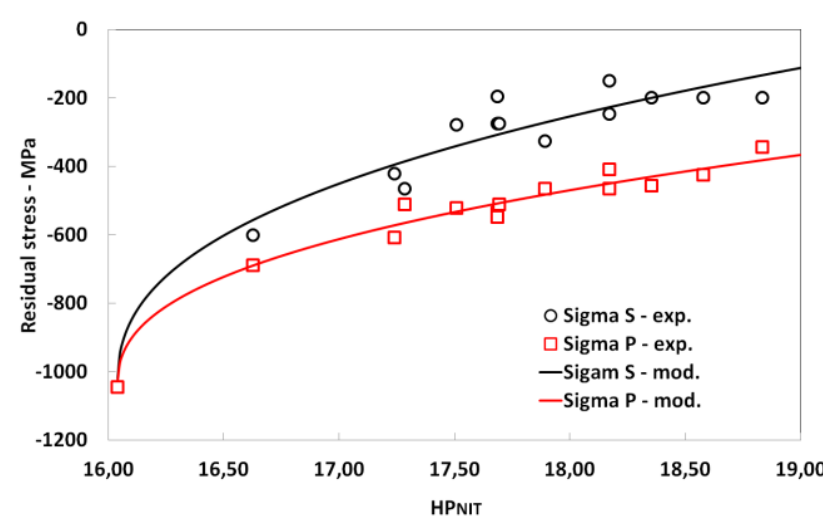

Figure 8: Surface $\sigma^{S}$ and peak $\sigma^{S}$ residual stress versus nitriding parameter $H P_{N I T}$

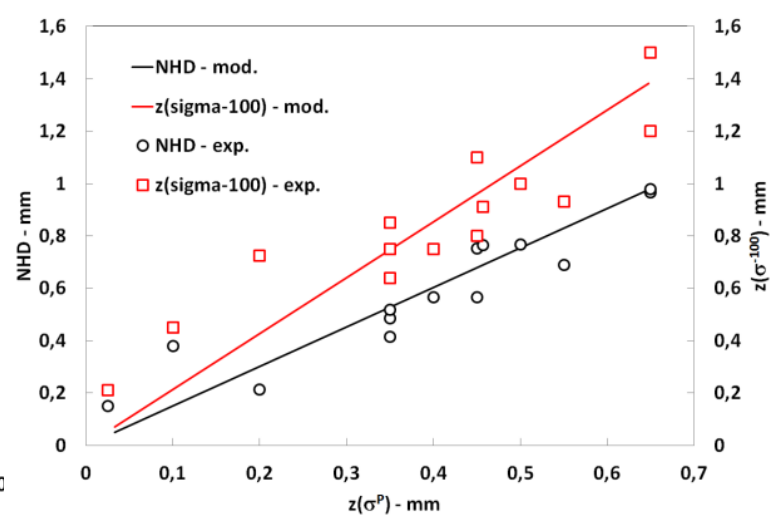

Figure $9: N H D$ and $z\left(\sigma^{-100}\right)$ as a function of $z\left(\sigma^{P}\right)$

All parameters needed for the model, their way of identification and the mean deviation between calculated and experimental values for all nitriding experiments are summarized in Table 2.

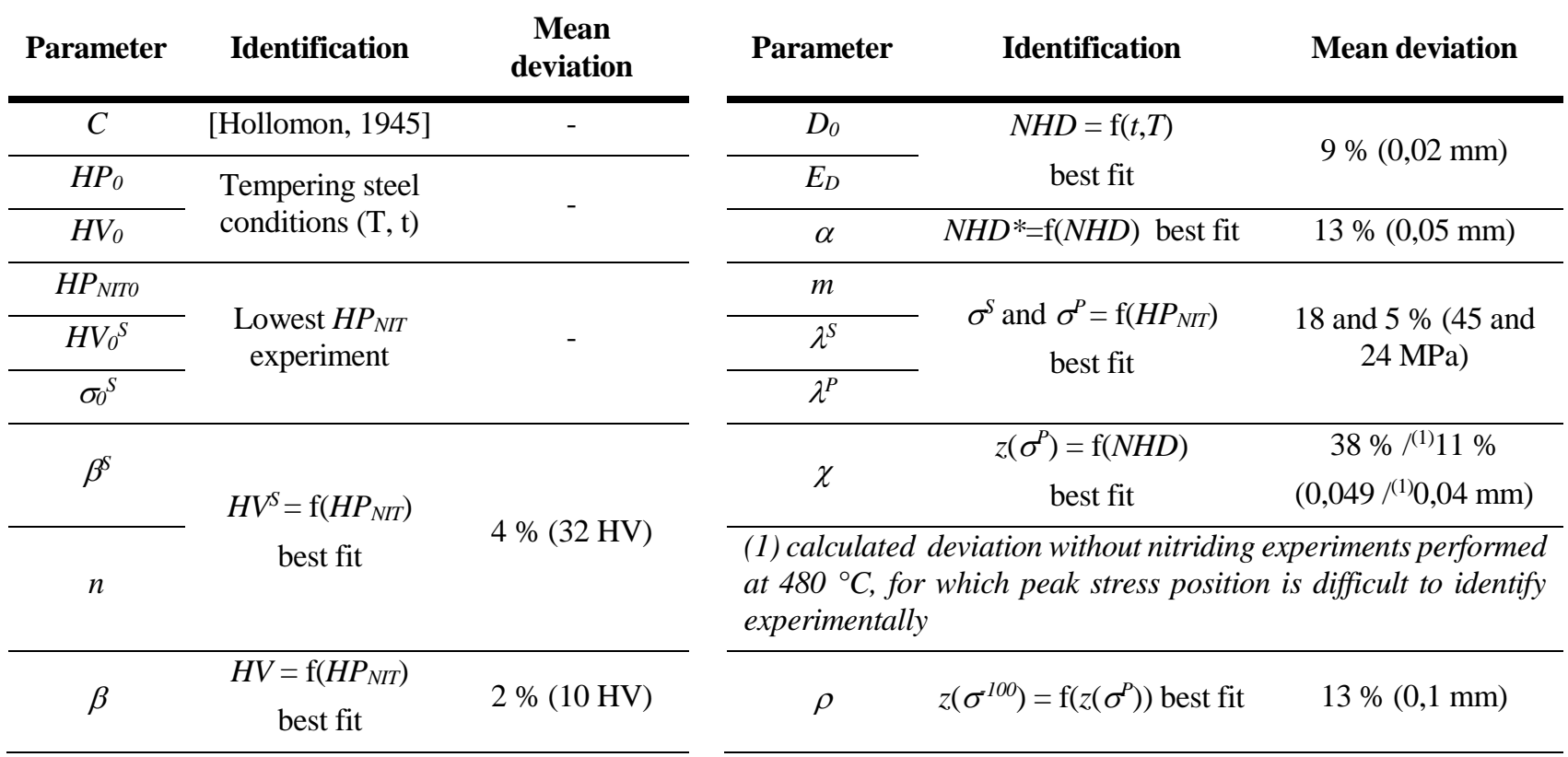

Table 2: Model parameters, their way of identification, and mean deviation between calculated and experimental value for the whole nitriding experiments

Parameters values leading to best fits were obtained by minimizing the error function defined in [10] with the Excel® solver.

$$
\text { error function }=\sum_{i=1}^{x}\left(I_{\text {exp }}-I_{\text {mod }}\right)^{2}
$$

Where $x$ is the number of experiments performed, $I_{\text {exp }}$ and $I_{m o d}$ are respectively the experimental and modelled indicator values.

Figure 10 gives a comparison between experimental and calculated profiles for three nitriding conditions, covering a large range of $H P_{N I T}$ values, $16.04,17.51$ and 18.83 (respectively $480^{\circ} \mathrm{C} / 20$ $\mathrm{h}, 550^{\circ} \mathrm{C} / 120 \mathrm{~h}$ and $580^{\circ} \mathrm{C} / 120 \mathrm{~h}$ ). It is important to remember that shape of hardness profile 
between surface hardness and NHD is not described since the assumption of the model is only suitable for surface and core.
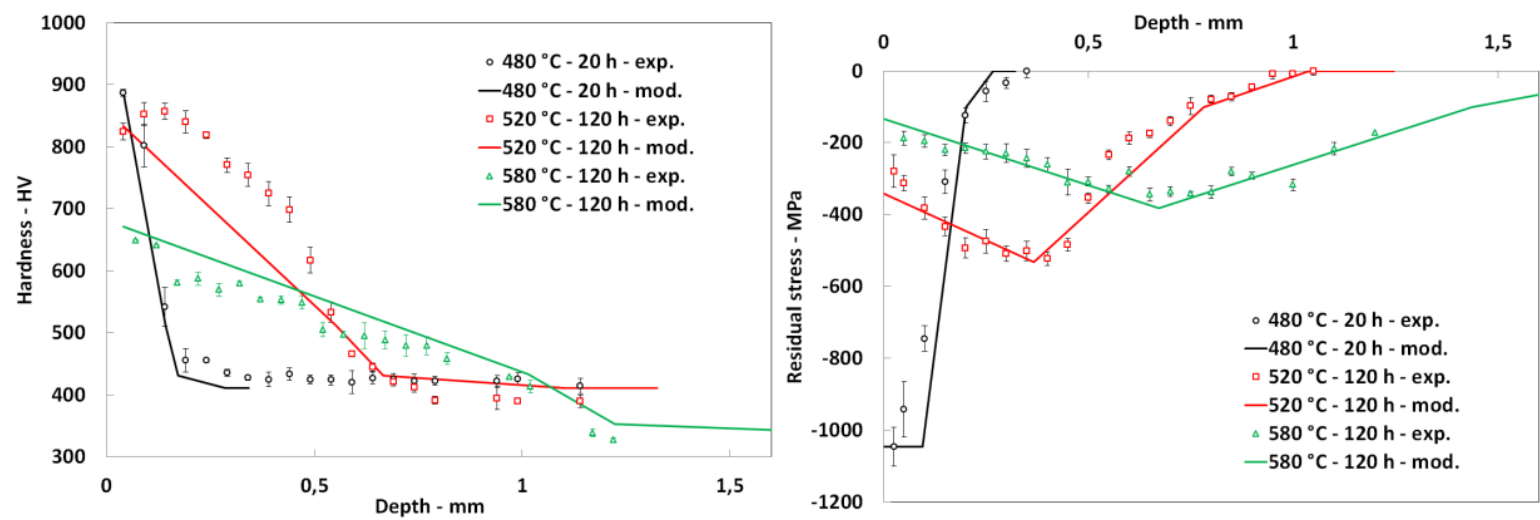

Figure 10: Model versus experiment for three nitriding conditions: hardness profile (left) and residual stress profile (right)

These experiments correspond to three tempering regimes (see Figure 5). For the lowest value of $H P_{N I T}$, case and core hardness are maximum and not yet affected by tempering effect. For the intermediate one, surface softening has begun whereas core hardness is not affected. For the higher one, both surface and core are softened because of nitriding-induced tempering. These different regimes are well described by our model. Residual stress profiles prediction is also convenient.

\section{Model validation}

In order to validate the proposed model, three new nitriding experiments, detailed in Table 3 , were done with the same $H P_{N I T}$ values but different values of $t$ and $T$. First of all, it can be seen in Figure 11 that nitriding treatments performed with the same $H P_{N I T}$ parameter lead to almost the same hardening laws. Previous nitriding results with close $H P_{N I T}$ value are also plotted to confirm our fundamental model assumption.

\begin{tabular}{cccc} 
Experiment & $\boldsymbol{t}(\mathbf{h})$ & $\boldsymbol{T}\left({ }^{\circ} \mathbf{C}\right)$ & $\boldsymbol{H P}_{\boldsymbol{N I T}}$ \\
\hline$\# 1$ & 200 & 520 & 17,69 \\
\hline$\# 2$ & 106 & 530 & 17,69 \\
\hline$\# 3$ & 58 & 540 & 17,69
\end{tabular}

Table 3: Nitriding experiments for the model validation 


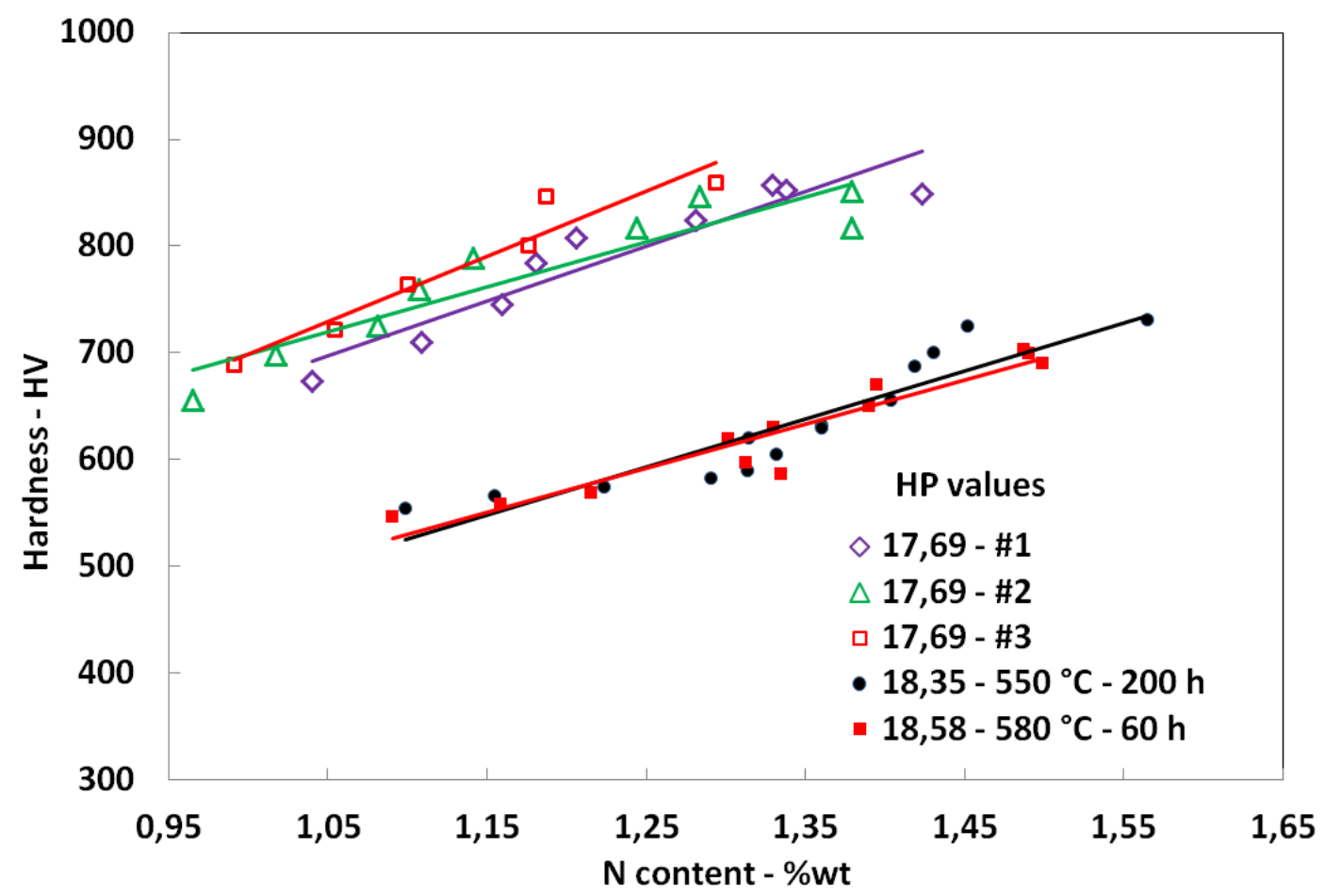

Figure 11: Hardening laws for nitriding experiments with close $H P_{N I T}$ values

A comparison is given in Figure 12 between experimental and calculated profiles for the three iso$H P_{N I T}$ treatments.
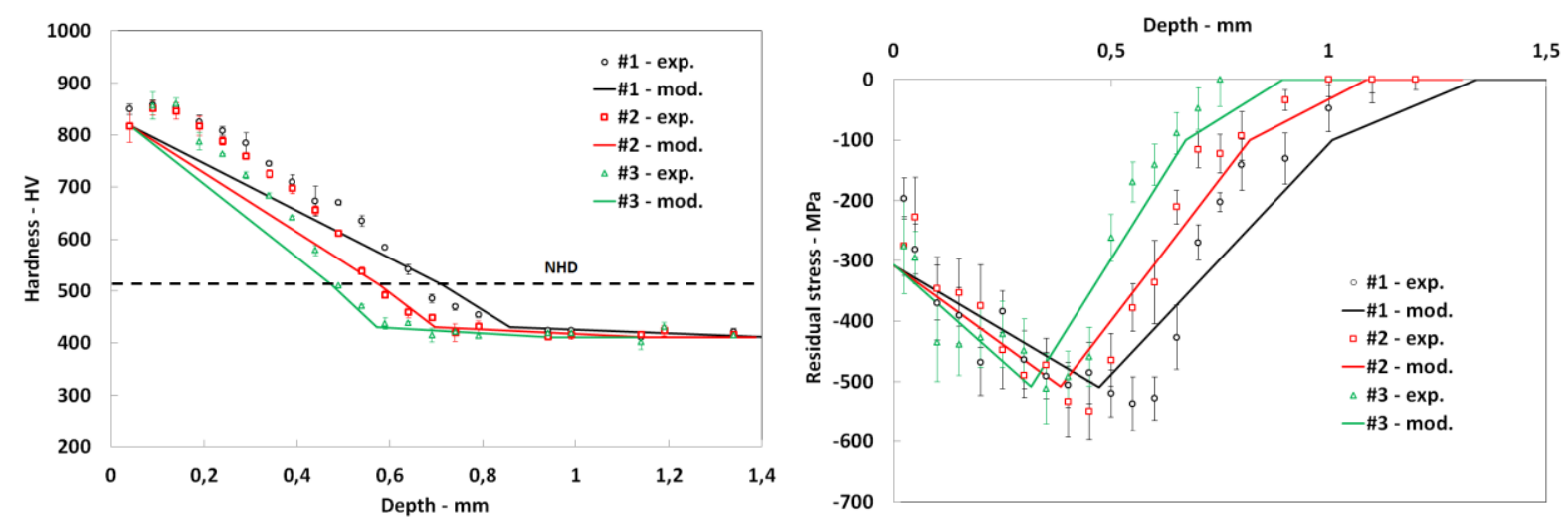

Figure 12: Model versus experiment for the three validation nitriding experiments. Hardness profiles (left) and residual stress profiles (right)

These results confirm globally the fact that a given $H P_{N I T}$ induces given surface and core hardness but also surface and maximum residual stress. A quite good estimation of both profiles is obtained with the model.

\section{Conclusion}

By scanning a large range of nitriding time and temperature, we demonstrated that hardness and residual stress profiles can be easily estimated by considering nitriding-induced tempering effects and basic diffusion calculation. This calculation can be performed thanks to a simple engineering parameter, $H P_{N I T}$. This parameter combines nitriding temperature and time effects on hardness and residual stress values. The relevance of this process parameter was demonstrated experimentally thanks to iso- $H P_{N I T}$ nitriding experiments. The model is presented in Figure 13 in an abacus shape. 
Nitriding conditions can be quickly identified from specified $N H D$, hardness and residual stress values.

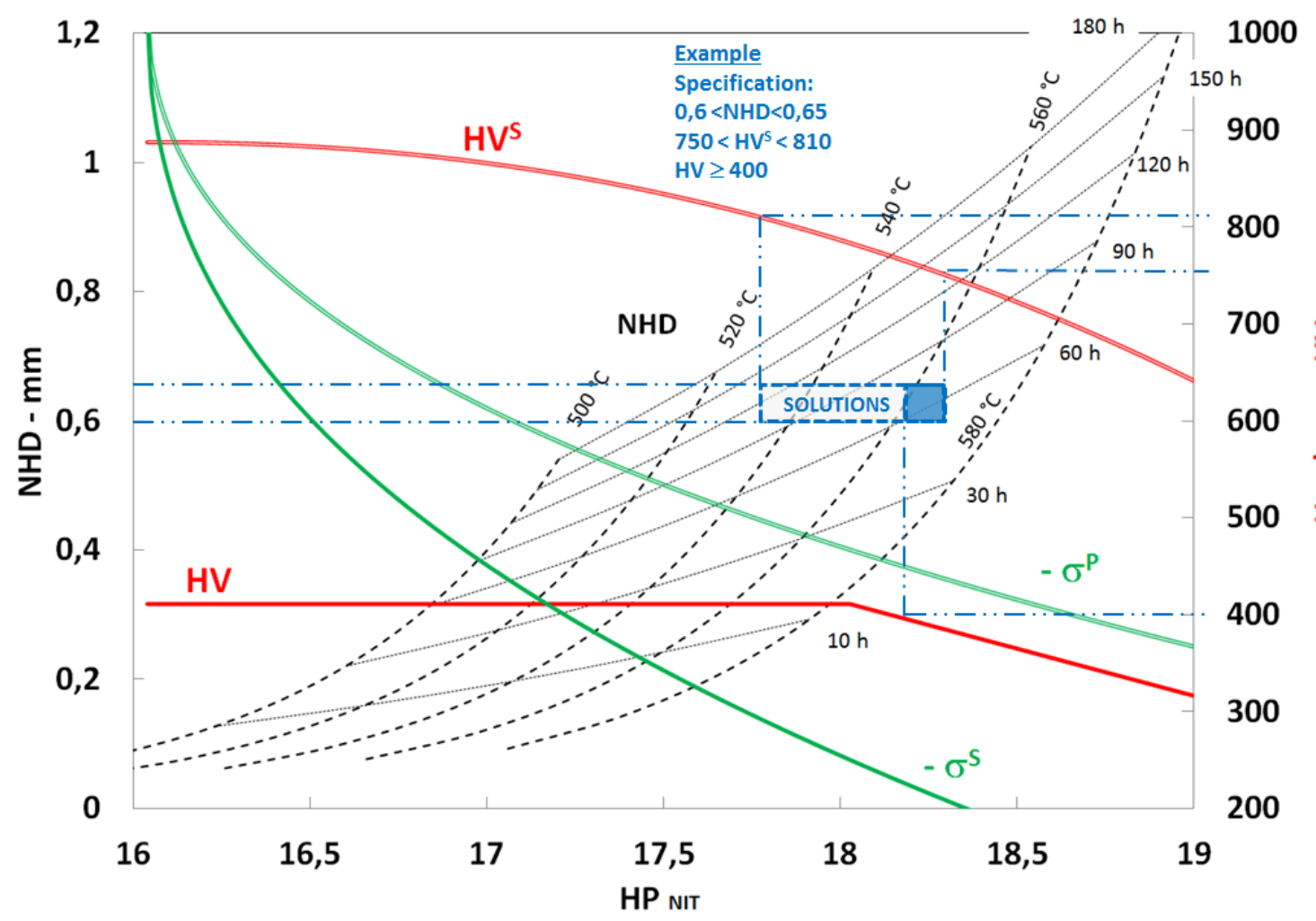

Figure 13: Abacus for $N H D$ (isothermal and isochronous black curves), $H V^{S}, H V$ (red curves), $-\sigma^{P}$ and $z\left(\sigma^{P}\right)$ (green curves) estimation from nitriding time and temperature traduced in terms of $H P_{N I T}$ for E33CrMov12-9 steel. An example of solutions complying requirements is given in blue.

Even though there is a unique nitriding solution for a determined specification, various nitriding solutions can be found for a range of targeted values. An example is given in Figure 13. The given specification (see top of Figure 13) can be achieved with a large range of nitriding duration (from about $60 \mathrm{~h}$ to $140 \mathrm{~h}$ ). In this case, nitriding temperature limitation comes from the core requirement. The resulting residual stress peak should vary between roughly -450 and $-500 \mathrm{MPa}$. Theoretically, the model parameters can be identified for another low-alloy nitriding steel or other pre-treatment, with only three experiments (including nitriding, hardness testing and residual stress measurement). Nevertheless, five experiments, uniformly distributed in the 16-19 $H P_{N I T}$ range are recommended.

\section{Acknowledgements}

This work was supported by the French government PIA (Programme d'Investissements d'Avenir) through the IRTM2P "NITRU" project. The authors deeply thank the other industrial partners (mentioned in alphabetic order): Airbus Group, Air-Liquide, ALD, Naval Group, Sofiplast, UTC Ratier-Figeac. The authors also thank Q. MILLEE (IRT$\mathrm{M} 2 \mathrm{P}$ ) for nitriding treatments and characterizations.

\section{References}

ASM Hanbook, Gas nitriding of steel, in Heat Treating, ASM International, vol. 4, 1991

L. Barrallier, Genèse des contraintes résiduelles de nitruration - Etude expérimentale et modélisation. PhD thesis, ENSAM, Aix-en-Provence, 1992

L. Barrallier, Classical nitriding of heat treatable steel, Thermochemical Surface Engineering of Steels. Woodhead Publishing. 2014, 392-411 
G. Fallot, Rôle du carbone lors de la nitruration d'aciers de construction et influence sur les propriétés mécaniques. $\mathrm{PhD}$ thesis, ENSAM, Aix-en-Provence, 2015

D. Ghribi, M. Octrue, P. Sainsot. Etude des ruptures internes des flancs des dentures, tooth flank fracture, Journées Transmissions Mécaniques, Lyon, 2016

C. Ginter, Influence des éléments d'addition sur l'enrichissement d'azote et le durcissement d'aciers nitrurés. PhD thesis, Université de Nancy, 2006

S.M. Hassani-Gangaraj, et al., The effect of nitriding, severe shot peening and their combination on the fatigue behavior and micro-structure of a low-alloy steel, International Journal of Fatigue 62, 2014, 67-76

Y. Hiraoka,Y. Watanabe, O. Umezawa, Practical model to predict diffusion layer's hardness profile in gas nitrided low alloy steel containing chromium. J.Japan Inst. Met.Mater.,vol. 80, 2016, 259-267

S. Hoja, Hoffman et al., Design of deep nitriding treatment for gears, Journal of Heat Treatment of materials, vol. 70 , 2015

Hollomon, Jaffe, Time-temperature relations in tempering steel, Trans. AIME, 1945

S. Jégou, L. Barrallier, G. Fallot, Optimization of gaseous nitriding of steels by multi-physics modelling. 23rd International Federation of Heat Treatment and Surface Engineering Congress 2016, 63-70, 2016

S. Jégou, L. Barrallier, G. Fallot, Gaseous nitriding behavior of 33CrMoV12-9 steel: Evolution of the grain boundaries precipitation and influence on residual stress development, Surface \&Coating Technology 339 (2018) 78-90

M. Jung, Meka, et al., Coupling Inward Diffusion and Precipitation Kinetics; the Case of Nitriding Iron-Based Alloys, Metallurgical and Material Transactions A, vol. 47A, 2016

V. Leskovšeka, B. Podgornikb, D. Nolanc, Modelling of residual stress profiles in plasma nitride tool steel. Material Characterization, vol. 59, 2008, 454-461

J.N. Locquet, Caractérisations métallurgiques et mécaniques de couches nitrurées, relation microstructure comportement. PhD thesis, ENSAMd'Aix-en-Provence,1998

V. Savaria, F. Bridier, P. Bocher, Predicting the effects of material properties gradient and residual stresses on the bending fatigue strength of induction hardened aeronautical gears, International Journal of Fatigue, vol. 85, 2016, 70-84

M.A.J. Somers, R.M. Lankreijer, E.J. Mittemeijer, Excess nitrogen in ferrite matrix of nitrided binary iron-bases alloys. Philosophical Magazine A, vol. 59, 1989, 353-378

H.J. Spies, Fatigue behaviour of nitrided steels, Steel Research, 1993

H.J. Spies, Case Structure and Properties of Nitrided Steels, Comprehensive Materials Processing, vol. 12, Elsevier, 2014

A.A. Walvekar, F. Sadeghi, Rolling Contact Fatigue of Case Carburized Steels, International Journal of Fatigue, vol. 95, 2017, 264-281

H. Weil, L. Barrallier, S. Jegou, N. Caldeira-Meulnotte, G. Beck, Optimization of gaseous nitriding of carbon ironbased alloy based on fatigue resistance modelling, International Journal of Fatigue, vol. 110, 2018, 238-245 